\title{
A new protodidelphid (Mammalia, Marsupialia, Didelphimorphia) from the Itaboraí Basin and its implications for the evolution of the Protodidelphidae
}

\author{
LEONARDO M. CARNEIRO ${ }^{1,2,3}$ \\ ${ }^{1}$ Programa de Pós-Graduação em Biodiversidade e Biologia Evolutiva, Prédio das Pós-graduações do Instituto de \\ Biologia, Interbloco B/C, Centro de Ciências da Saúde (CCS), Campus Ilha do Fundão, Universidade Federal do Rio \\ de Janeiro/UFRJ, Avenida Carlos Chagas Filho, 373, Cidade Universitária, 21941-590 Rio de Janeiro, RJ, Brazil \\ ${ }^{2}$ Laboratório de Mastozoologia/LAMAS, Departamento de Zoologia, Universidade Federal do Estado \\ do Rio de Janeiro, Avenida Pasteur, 458, Sala 501, Urca, 22290-240 Rio de Janeiro, RJ, Brazil \\ ${ }^{3}$ Laboratório de Paleontologia e Paleoecologia da Sociedade de História Natural, Travessa \\ Florêncio Augusto Chagas, $n^{\circ}$ 8B, 2560-230, Torres Vedras, Portugal \\ Manuscript received on May 4, 2018; accepted for publication on July 19, 2018
}

\begin{abstract}
How to cite: CARNEIRO LM. 2019. A new protodidelphid (Mammalia, Marsupialia, Didelphimorphia) from the Itaboraí Basin and its implications for the evolution of the Protodidelphidae. An Acad Bras Cienc 91: e20180440. DOI 10.1590/0001-3765201820180440.
\end{abstract}

\begin{abstract}
The Protodidelphidae was a group of marsupials that lived in Gondwana from the early to middle Eocene. Among South American faunas, the Itaboraí Basin calls attention by the presence of four genera and six species. Herein is described Bergqvistherium primigenia gen. et sp. nov., a new protodidelphid from the Itaboraí Basin - lower Eocene. This taxon differs from other protodidelphids in the smaller size, developed entocristid, less brachyo-bunoid adaptations, and entoconid more mesial than the hypoconid. These characters are recovered as plesiomorphies of the Protodidelphidae, supporting Bergqvistherium as an early-divergent lineage of this group. The Protodidelphidae fauna of the Itaboraí Basin is represented by less specialized "basal" taxa, such as Bergqvistherium and Periprotodidelphis; and more specialized apical taxa, such as Guggenheimia, Protodidelphis, and Carolocoutoia. This result indicates that the diversification of apical protodidelphids probably was a result of a relatively short-time event, occurring during the early Eocene. This evolutionary event can be directly correlated to the increase in the temperatures and the extension of tropical forests resulted by the Paleocene-Eocene Thermal Maximum during the Itaboraiense time span. The study supported a Late Cretaceous origin for the Protodidelphidae, which agrees with molecular studies for the Didelphimorphia.
\end{abstract}

Key words: Metatheria, Paleogene, systematics, teeth.

E-mail: leonardo.carneiro8@gmail.com

ORCid: https://orcid.org/0000-0001-9385-431X

* Contribution to the centenary of the Brazilian Academy of Sciences. 


\section{INTRODUCTION}

The Protodidelphidae Marshall, 1987, is an extinct marsupial lineage that existed during the early and middle Eocene in South America and Antarctic Peninsula (Paula Couto 1952, 1962, 1970, Marshall 1987, Goin et al. 1999, Tejedor et al. 2009, Oliveira and Goin 2011, 2012) and (Oliveira É.V., unpublished data). This taxon is represented by Protodidelphis Paula Couto 1952; Guggenheimia Paula Couto, 1952; Carolocoutoia Goin et al. 1998; and Periprotodidelphis Oliveira and Goin, 2011.

The oldest occurrences of this lineage are known for the Itaboraí Basin, Rio de Janeiro, Brazil, and Las Flores, Argentina; both considered as lower Eocene (Itaboraian SALMA - around 55-52 Ma - Woodburne et al. 2014a) in age. All members of the Protodidelphidae are known to have existed during this time span. The youngest fossil records are known for the La Meseta Formation, Antarctica, and Paso del Sapo, Argentina; both date from the lower-middle Eocene ("Sapoan" SALMA) (Goin et al. 1999, Tejedor et al. 2009), which identifies the Protodidelphidae as a short time span surviving lineage during the Paleogene of South America. Notwithstanding, the evolution of other metatherian lineages can be traced back to the Paleocene of South America or even to the Late Cretaceous of North America (Case et al. 2005, Forasiepi et al. 2009, Goin et al. 2012, 2016, Oliveira and Goin 2012, Carneiro and Oliveira 2017a, b, Carneiro 2018), which is also expected for the Protodidelphidae.

The Paleocene metatherian fossil bearing localities in South America are restricted to Tiupampa, Bolivia (lower Paleocene - Tiupampian SALMA - Muizon 1992); Laguna Umayo, Peru (upper Paleocene or Itaboraian SALMA - Sigé et al. 2004, Gelfo and Sigé 2011); Grenier section of the Lefipán Formation, Argentina (lower Paleocene - Goin et al. 2006), and Punta Peligro, Argentina (lower Paleocene - Peligran
SALMA - Woodburne et al. 2014b); however, none of these localities have a protodidelphid among the identified metatherians. The Paleocene diversification of the Protodidelphidae can be inferred based on the great diversity of this group during the Itaboraian SALMA (early Eocene), as four genera are recorded, as commented. Among them, Guggenheimia is considered by Oliveira and Goin (2011) as an early-divergent lineage of the Protodidelphidae based on the relatively smaller size and less bunoid molars. Nevertheless, this genus shows several morphological traits that support an earlier evolutionary history for the Protodidelphidae.

During a survey of the paleontological collection in the Departamento Nacional de Produção Mineral (DNPM), an isolated m3 of a 'protodidelphid-like' taxon was identified in the fossils collected in 1968, which differs in several ways from other genera from the Itaboraí Basin. Interestingly, this material is similar in some morphological traces to Guggenheimia; however, it bears some plesiomorphic characters for a brachyobunoid taxon, supporting a probable earlier divergence.

Here, it is described a new genus of protodidelphid from the Itaboraí Basin, discussing its implications for the evolution of the Protodidelphidae and for the fauna of the Itaborai Basin.

Institutional abbreviations: AMNH, American Museum of Natural History, New York, New York, USA; MCN-PV, Museu de Ciências Naturais da Fundação Zoobotânica do Rio Grande do Sul, Porto Alegre, Brazil; DNPM, Departamento Nacional de Produção Mineral, Rio de Janeiro, Brazil; MCT (ex DGM, Divisão de Geologia e Mineralogia), Museu de Ciências da Terra, Rio de Janeiro, Brazil; MLP, Museo de La Plata, Facultad de Ciencias Naturales y Museo, Universidad Nacional de La Plata, La Plata, Argentina; MN, Museu Nacional, Rio de Janeiro, Brazil. 
Other abbreviations: m, lower molars with the numbers corresponding to its positioning; EECO, Early Eocene Climatic Optimum; PETM, Paleocene-Eocene Thermal Maximum; SALMA, South American Land Mammal Age; SEM, Scanning Electron Microscope.

\section{MATERIALS AND METHODS}

The type specimen of the new taxon (i.e. MCT $4387-$ $\mathrm{M}$ - see below) is deposited at the Departamento de Produção Mineral (DNPM), Rio de Janeiro, Brazil. The type specimen is from the Itaboraí Basin, São José de Itaboraí, Rio de Janeiro, Brazil (2245'9.9144”'S, 4251'53.5536”W) (Fig. 1).

The Brazilian taxa were directly analyzed (i.e. fossil specimens and casts), in addition,

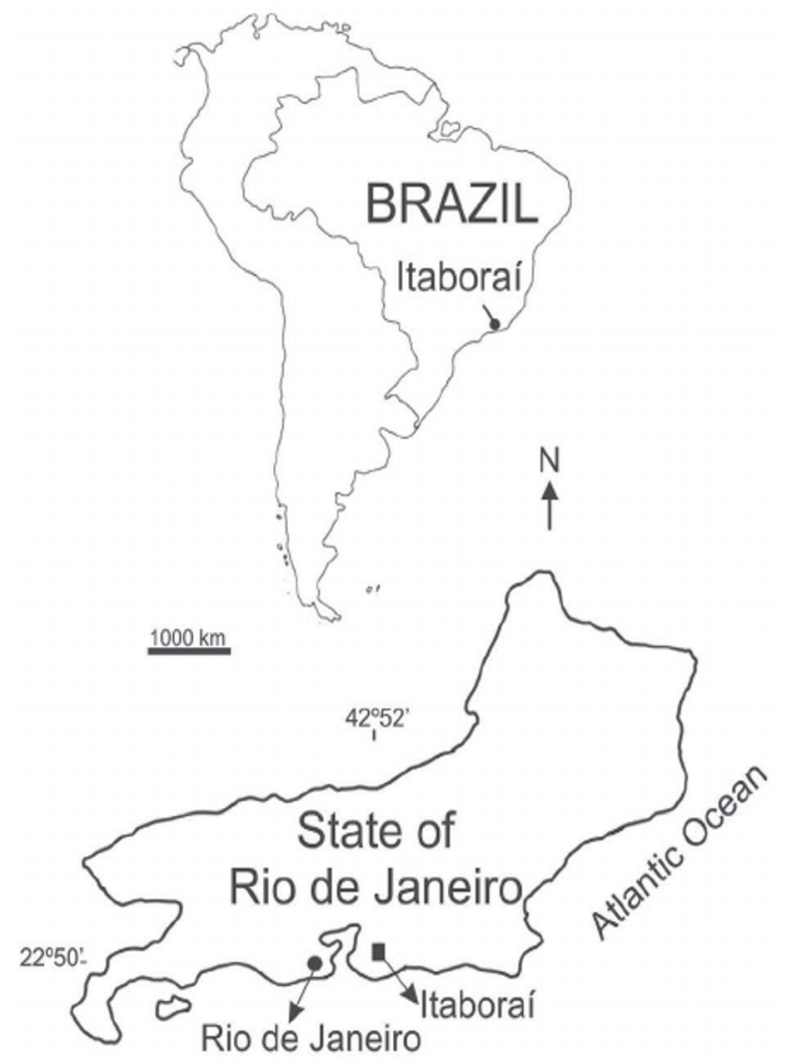

Figure 1 - Location map showing the region and coordinates of the Itaboraí Basin, São José de Itaboraí, Rio de Janeiro, Brazil (22 45 '9.9144"'S, 4251'53.5536"W). Figure adapted from the figure 1 (p. 106) from Oliveira and Goin (2011). literature descriptions, casts, digital and SEM pictures were also analyzed. The North American taxa were studied based on literature descriptions, casts, digital and SEM pictures. The casts of Naturita Formation taxa and several specimens of Varalphadon were sent by Richard L. Cifelli and Joshua E. Cohen from the Sam Noble Oklahoma Museum of Natural History, USA. A list of casts is given in the supplementary material, that can be accessed here https://www.researchgate.net/ publication/327248822_Supplementary_Material.

The SEM pictures of the new taxon were made with the scanning electron microscope JEOL JSM6390LV at the Centro de Microscopia Eletrônica de Varredura do Departamento de Invertebrados do Museu Nacional, Museu Nacional, Rio de Janeiro, Brazil.

The data matrix is based on the characters published in Ladevèze and Muizon (2010), Luo et al. (2011), Abello (2013), Forasiepi et al. (2015), Muizon et al. (2015), Wilson et al. (2016), Beck (2017), Carneiro and Oliveira (2017a, b), and Carneiro (2018). The matrix is based mainly on dental characters from upper and lower dentition of fossil and living metatherians.

The morphological matrix was submitted to a new technology search with TNT 1.5 (Goloboff and Catalano 2016) using the sectorial, ratchet, drift and tree fusing strategies with 500 replications. The morphological matrix is available as supplementary material, also at https:/www.researchgate.net/ publication/327248822_Supplementary_Material. Bremer supports and tree scores were calculated with TNT 1.5. The phylogeny presents 642 unordered characters, including cranial, dentary, dental and postcranial characters, and 184 therian taxa, including more than 170 metatherians and closely related taxa, from the Cretaceous and Cenozoic of North America, Asia, South America, Antarctic, Europe and Australia. 


\section{SYSTEMATIC PALEONTOLOGY}

Mammalia Linnaeus, 1758

Metatheria Huxley, 1880

Marsupialiformes Vullo et al. 2009

Notometatheria Kirsch et al. 1997

Marsupialia Illiger, 1811 (McKenna and Bell 1997)

Order Didelphimorphia Gill, 1872

$†$ Family Protodidelphidae Marshall 1987

$†$ Genus Bergqvistherium gen. nov.

(Fig. 2)
ZooBank Life Science Identifier (LSID) urn:1sid:zoobank.org:act:0DDF46FB-B2DF-467CA8D5-96F03CB989E6

Etymology: 'Bergqvist', in honor of Lílian Paglarelli Bergqvist for her contributions for the knowledge of the Itaboraí Basin; 'therium', from the Greek, beast; a common designation of fossil mammals. Gender is feminine.

Type species: Bergqvistherium primigenia sp. nov.

Included species: The type only.

Diagnosis: Differs from other protodidelphids in the smaller size, less brachyo-bunoid lower molars, greater labiolingual compression and lesser mesiodistal compression of the trigonid, paraconid
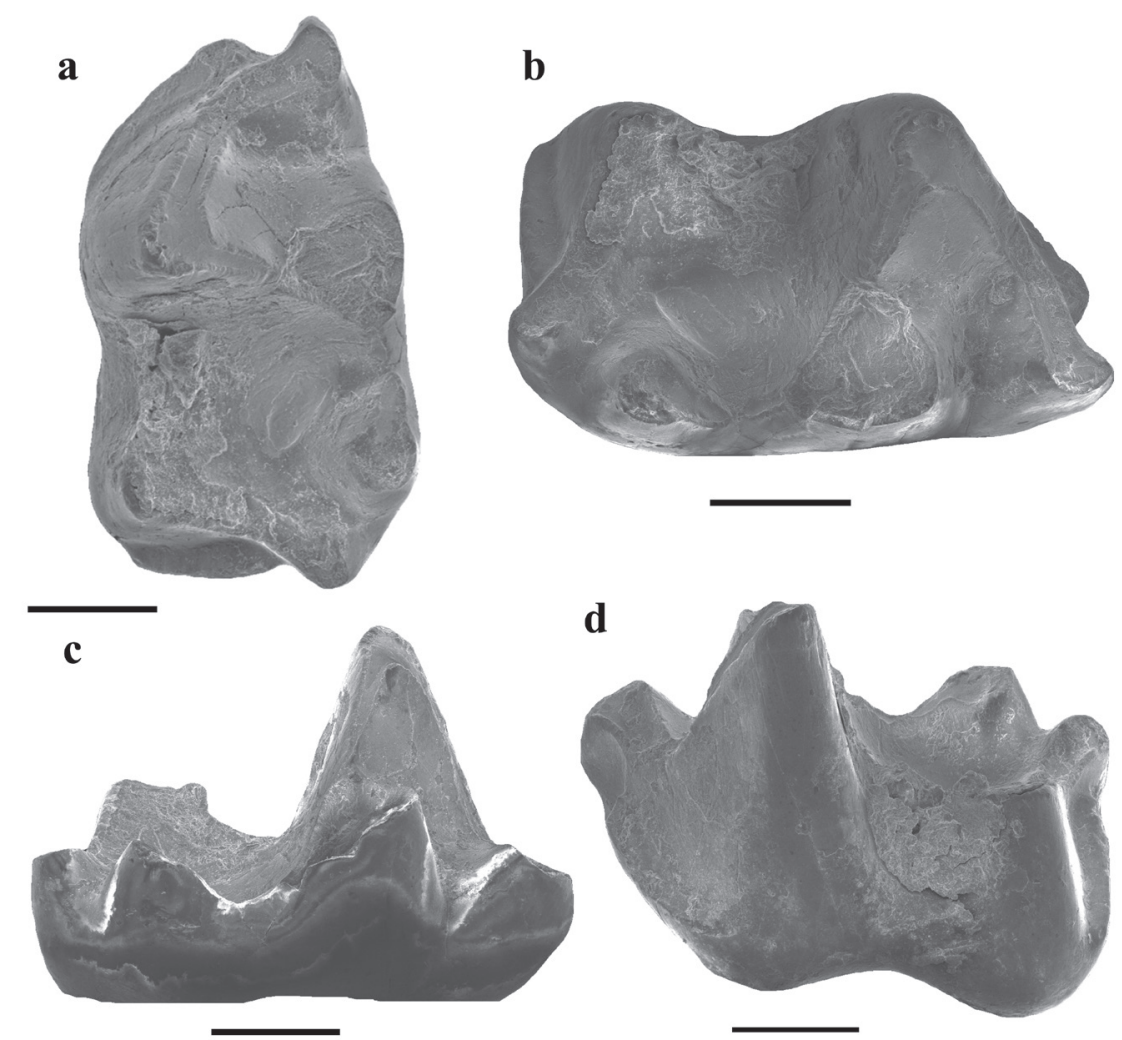

Figure 2 - Type specimen of Bergqvistherium primigenia. SEM pictures of the type specimen of Bergqvistherium primigenia (MCT 4387-M), a left m3: a, occluso-labial; b, occlusal; c, lingual; d, labial views. Scale bar: $0,5 \mathrm{~mm}$. 
less lingually shifted and more mesiodistally developed, paraconid apex mesially oriented, paracristid with a straight shape in occlusal view, greater development of the entocristid, and greater development of the posterobasal cingulid. Differs from Guggenheimia brasiliensis and G. crocheti in the following combination of characters: entoconid mesial to hypoconid, more developed paraconid, less brachyo-bunoid lower molars; greater development of the distolabial crest of the metaconid and developed entocristid. Differs from Guggenheimia sp. from Las Flores, Argentina (e.g. MLP 90-II-5-79, a left m3; and MLP 90-II-5-72, a right $\mathrm{m} 3$ ), in the presence of a much less inflated entoconid, paracristid not "curved", paraconid less lingually positioned than metaconid, greater development of the entocristid, distolabial crest of the metaconid, anterobasal cingulids; and trigonid not so mesiodistally compressed. Differs from Periprotodidelphis and Carolocoutoia in the much smaller size and less inflated molar. Differs from Protodidelphis in the markedly smaller size, less bunoid molar, less inflated and conical entoconid, entoconid mesial to hypoconid and paraconid more developed (Fig. 3).

Type locality: Fresh water travertine deposits of the fissure explored in 1968 at São José de Itaboraí, Rio de Janeiro, Brazil (Bergqvist et al. 2009). Itaboraí Formation, lower Eocene in age Woodburne et al. (2014a).

Locality and horizon: Fissure discovered and worked in 1968, of the Itaboraí Formation, Itaboraí Basin, municipality of Itaboraí, State of Rio de Janeiro, Brazil (Bergqvist et al. 2009). Lower Eocene, Itaboraian SALMA (ca 53-50 Ma; sensu Woodburne et al. 2014a).

$\uparrow$ Bergqvistherium primigenia sp. nov.

(Fig. 2)
Etymology: 'primigenia' from the Greek 'primigenius' ('primus' = first; 'genus' = origin, birth) in reference of its earlier divergent condition to other protodidelphids.

Diagnosis: As for the genus.

Holotype: MCT 4387-M, a left m3 (Fig. 2).

Hypodigm: The type only.

Locality and horizon: As for the genus.

Description: The $\mathrm{m} 3$ is $2,16 \mathrm{~mm}$ in mesiodistal length, $1,29 \mathrm{~mm}$ in the labiolingual width of the trigonid, and 1,26 $\mathrm{mm}$ in the labiolingual width of the talonid. The paraconid is moderately developed and slightly more labially positioned than the metaconid, and its apex is mesially projected. The paracristid is short and does not show a "curved" shape. The trigonid is mesiodistally and labiolingually compressed. The metaconid is slightly distal (i.e. nearly aligned) to the protoconid. The entoconid is conical, and welldeveloped, but not massive (i.e. does not occupy most of or the entire lingual half of the talonid basin). The entocristid and the distolabial crest of the metaconid are developed. The hypoconid is distal to the entoconid. The cristid obliqua contacts the distal wall of the trigonid somewhat more labial than the carnassial notch. The hypoconulid is moderately developed and is twinned to the entoconid, but is not distolingual in position. The anterobasal cingulid is moderately developed and the posterobasal cingulid is well-developed.

Measurements: See Table I.

Remarks: Bergqvistherium primigenia is considered to be a protodidelphid based on the presence of a conical and well-developed entoconid, brachyodont molar, developed cingulids, metaconid distal to protoconid, paraconid slightly more lingual than the metaconid, and paraconid with some degree of mesiodistal compression. 


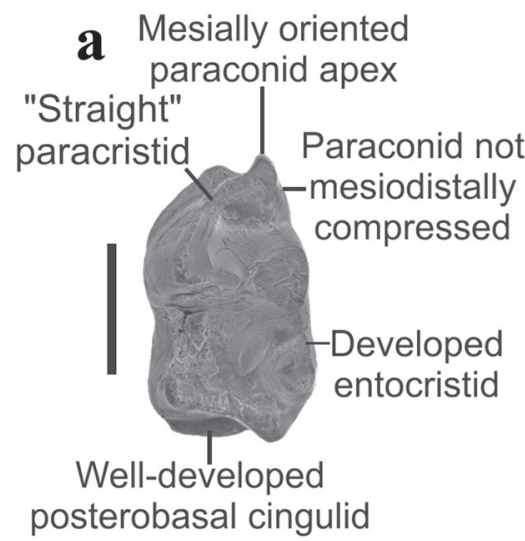

Bergqvistherium primigenia

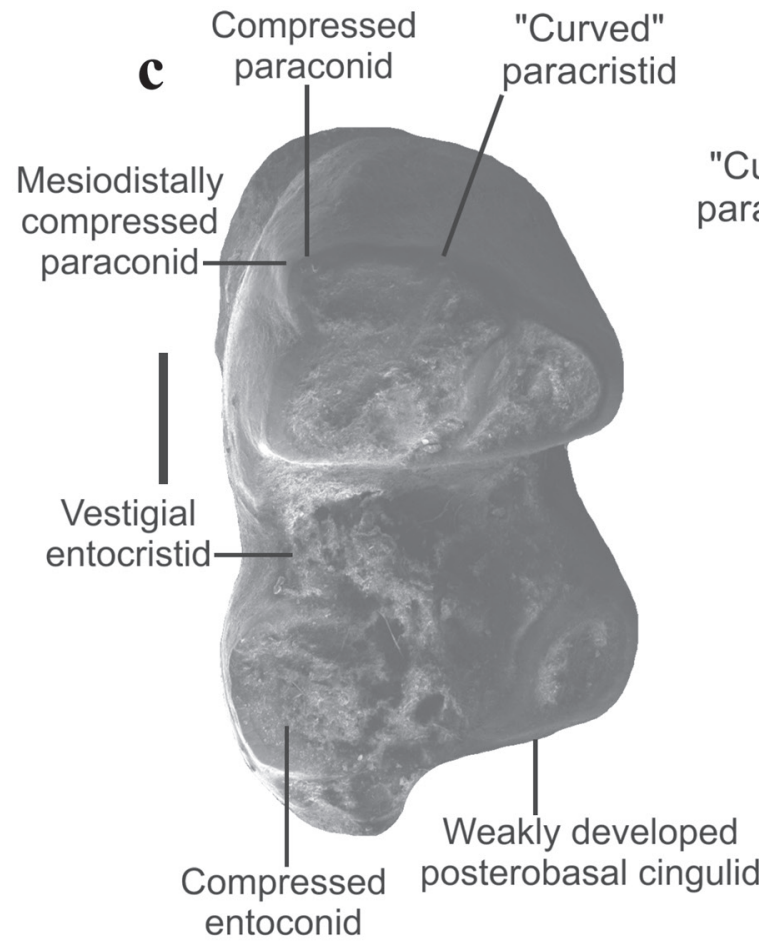

Protodidelphis vanzolinii

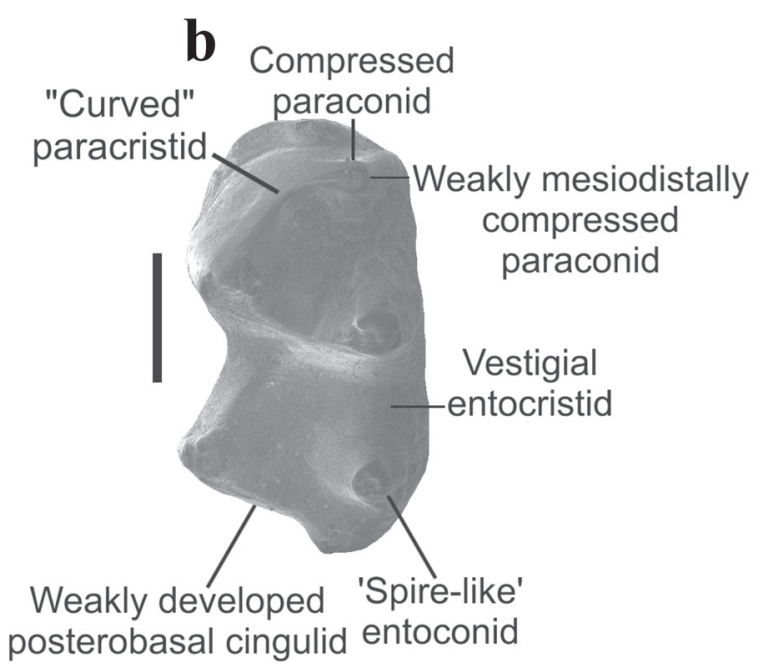

Guggenheimia crocheti

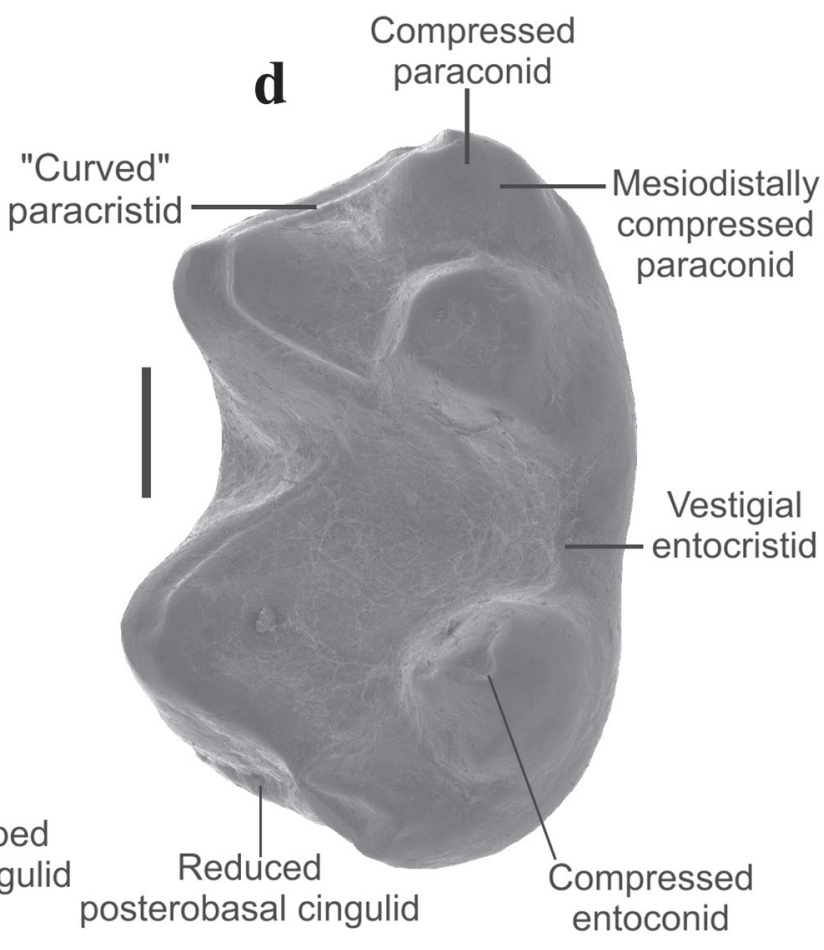

Protodidelphis mastodontoides

Figure 3 - Comparative morphology of the lower molars of the Brazilian protodidelphids. Differential morphology between Bergqvistherium, Guggenheimia and Protodidelphis: a, Bergqvistherium primigenia: MCT 4387-M, a left m3 (type specimen), in occlusal view; b, Guggenheimia crocheti: DGM 314-M, an incomplete left dentary with m2-4 and alveoli of i1-m1 (type specimen), showing the $\mathrm{m} 3$ in occlusal view; c, Protodidelphis vanzolinii: DGM 250-M, nearly complete right dentary, showing the $\mathrm{m} 3$ in occlusal view; d, Protodidelphis mastodontoidea: MCT 2819-M, left $\mathrm{m} 2$ in occlusal view. The proportional size difference between these taxa is preserved. Scale bars: $1 \mathrm{~mm}$. 
TABLE I

Measurements (mm) of the third lower molars (m3) of Bergqvistherium primigenia gen. et sp. nov and other protodidelphids. The size range of known specimens is indicated and based on the specimens from the Museu Nacional (MN), Rio de Janeiro; Museu de Ciências da Terra (MCT), Rio de Janeiro; Museu de Ciências Naturais da Fundação Zoobotânica do Rio Grande do Sul (MCN-PV), Porto Alegre, Brazil; and American Museum of Natural History (AMNH), New York, USA. Length: mesiodistal axis; width: labiolingual axis.

\begin{tabular}{ccc}
\hline Taxa & m3 length & m3 width \\
\hline $\begin{array}{c}\text { Bergqvistherium } \\
\text { primigenia } \\
\begin{array}{c}\text { Guggenheimia } \\
\text { brasiliensis }\end{array}\end{array}$ & $2,16 \mathrm{~mm}$ & $1,29 \mathrm{~mm}$ \\
$\begin{array}{c}\text { Guggenheimia crocheti } \\
\text { Protodidelphis vanzolinii }\end{array}$ & $3,16-3,2 \mathrm{~mm}$ & $1,77-2,02 \mathrm{~mm}$ \\
$\begin{array}{c}\text { Protodidelphis } \\
\text { mastodontoides }\end{array}$ & $5,81-6,5,5 \mathrm{~mm}$ & $3,4-3,67 \mathrm{~mm}$ \\
\hline
\end{tabular}

It should not be considered as belonging to the Chulpasiinae as it lacks a talonid somewhat wider than trigonid, the entoconid is relatively less developed (i.e. not massive developed), the hypoconulid is relatively smaller, and the paraconid is relatively narrower and more mesiodistally compressed.

\section{PHYLOGENETIC ANALYSIS AND SYSTEMATIC IMPLICATIONS}

The analysis found 24 most parsimonious trees (trees score $=2944 ; \mathrm{CI}=0.296 ; \mathrm{HI}=0.704$; RI $=0.669)$ (Fig. 4). Following the results, Bergqvistherium is recovered as the sister taxon of Periprotodidelphis + Anatoliadelphys and Guggenheimia, Protodidelphis + Carolocoutoia, as an early-divergent lineage of the Protodidelphidae.

The Protodidelphidae is the sister taxon of the Glasbiidae Clemens, 1966; which is represented by Palangania, Periakros and Glasbius. Protodidelphidae and Glasbiidae are the sister taxa of Reigia. The Protodidelphidae, Glasbiidae and Reigia are recovered as the sister taxon of the Didelphoidea, which is represented by the Didelphidae, Sparassocynidae and Monodelphopsis. These lineages represent the Didelphimorphia and can be considered as belonging to the Marsupialia (Fig. 4). The inclusion of the Protodidelphidae among the Didelphimorphia was supported by the analyses of Ladevèze and Muizon (2010), Carneiro and Oliveira (2017a, b) and Carneiro (2018).

The pylogenetic analysis support the sister relation between Periprotodidelphis and Anatoliadelphys, recovering a South American ancestral area for the lineage of the last taxon. This result differs from the one of Maga and Beck (2017), who proposed a North American ancestor area for Anatoliadelphys. This result can be considered as preliminary evidence supporting the hypothesis of the Atlantogea, as proposed by Ezcurra and Agnolín (2012).

\section{DISCUSSION}

\section{THE LATE CRETACEOUS-EARLY PALEOGENE ORIGIN OF THE PROTODIDELPHIDAE}

The PETM (Paleocene-Eocene Thermal Maximum) probably occurred around 55,2 Ma, with the increase of the global temperatures and the extension of tropical forests (Bowen et al. 2015). This event is correlated with the increase in abundance and diversity of metatherians in South America, especially bachyo-bunoid taxa, such as the Protodidelphidae and the Polydolopimorphia, as recorded in the localities dating back to the Itaboraian SALMA (Woodburne et al. 2014a, b, Goin et al. 2016).

The presence of five different genera with seven species among the metatherian assemblage of the Itaboraí Basin (i.e. Bergqvistherium primigenia, Guggenheimia brasiliensis, G. crocheti, Periprotodidelphis bergqvistae, Protodidelphis vanzolinii, P. mastodontoides and Carolocoutoia ferigoloi) supports the diversification of the Protodidelphidae beginning earlier than the 


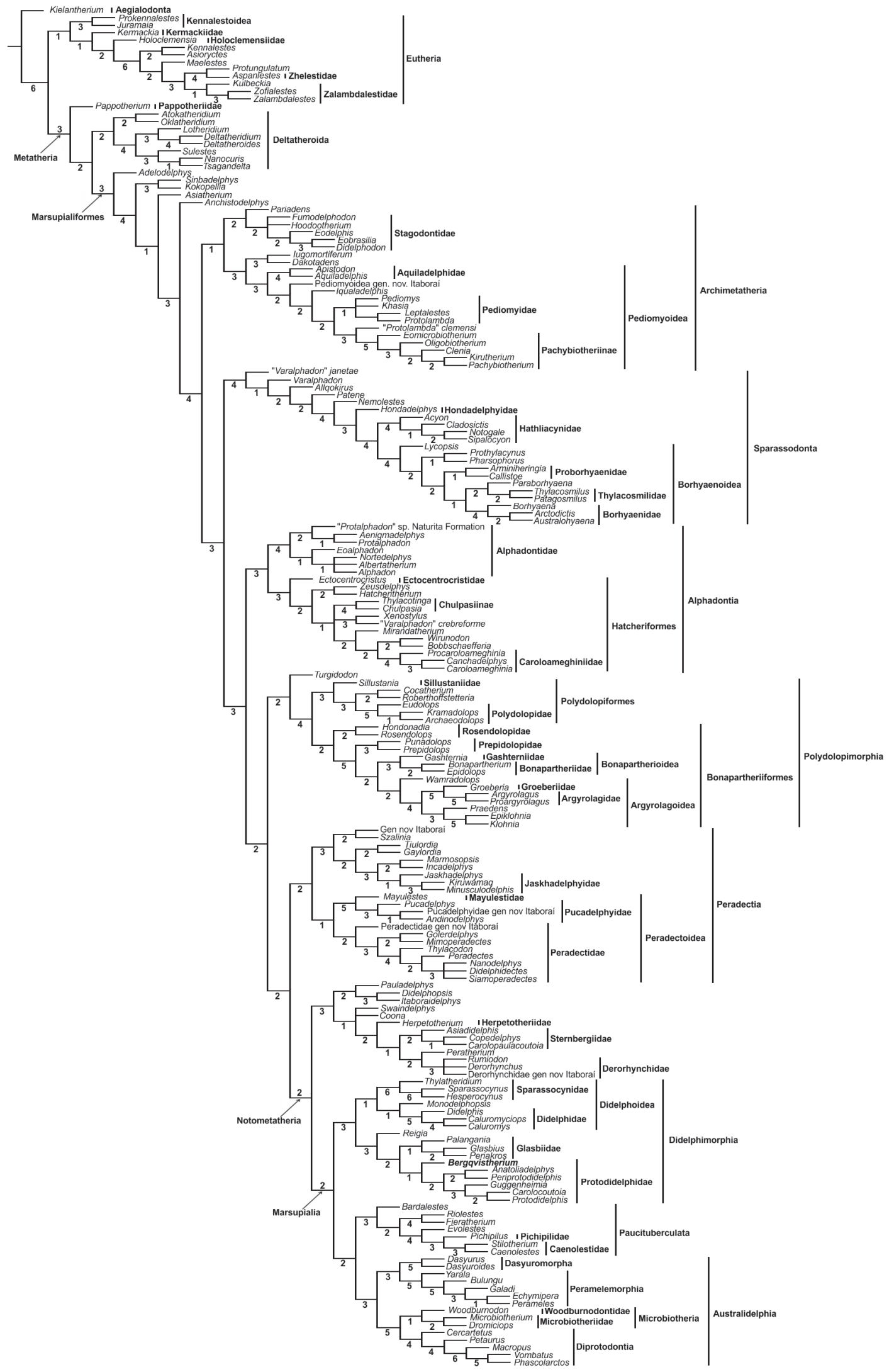


Figure 4 - The result of the phylogenetic analysis. Consensus tree of the 24 most parsimonious trees found in the analysis. Bergqvistherium is highlighted in bold. Numbers below the branches indicate the Bremer Support.

Itaboraian SALMA time span (i.e. early Eocene sensu Woodburne et al. 2014a).

The phylogenetic analysis recovered Glasbius as an apical glasbiid, which indicates that the lineages of the other glasbiid (i.e. Palangania and Periakros), Reigia and the Protodidelphidae existed by the time of the oldest fossil records of the former taxon in the USA (i.e. around $66 \mathrm{Ma}$, latest Maastrichtian - Clemens 1966, Davis 2007, Williamson et al. 2012, 2014, Boyd et al. 2017). If correct, these results support a Late Cretaceous origin of the Protodidelphidae, with this group surviving as a rare lineage in the faunas of South America before the PETM.

This evidence should not be treated as surprising, as molecular studies date the origin of the Didelphimorphia to the Santonian-early Campanian time span during the Late Cretaceous, around 8079 Ma (Kirsch et al. 1997, Bininda-Emonds et al.
2007), which is a compatible time span for the results recovered by the phylogenetic analysis.

The apical position of Glasbius among the glasbiid and the early Campanian (Late Cretaceous) origin of the Didelphimorphia indicate that Marsupialia did not evolve in North America during the Late Cretaceous. This result supports an 'Aves Ridge' or Gondwanan origin for the Didelphimorphia and Marsupialia.

THE PROTODIDELPHIDAE FAUNA OF THE ITABORAI BASIN: EVIDENCE OF A SHORT-TIME DIVERSIFICATION DURING THE ITABORAIENSE

Among the protodidelphids found in the Itaborai Basin, Periprotodidelphis and Bergqvistherium are represented just by a single tooth; while a far more abundant Protodidelphis (30 teeth for both species) and a moderately more abundant Guggenheimia (seven teeth) are also recorded (Oliveira and Goin

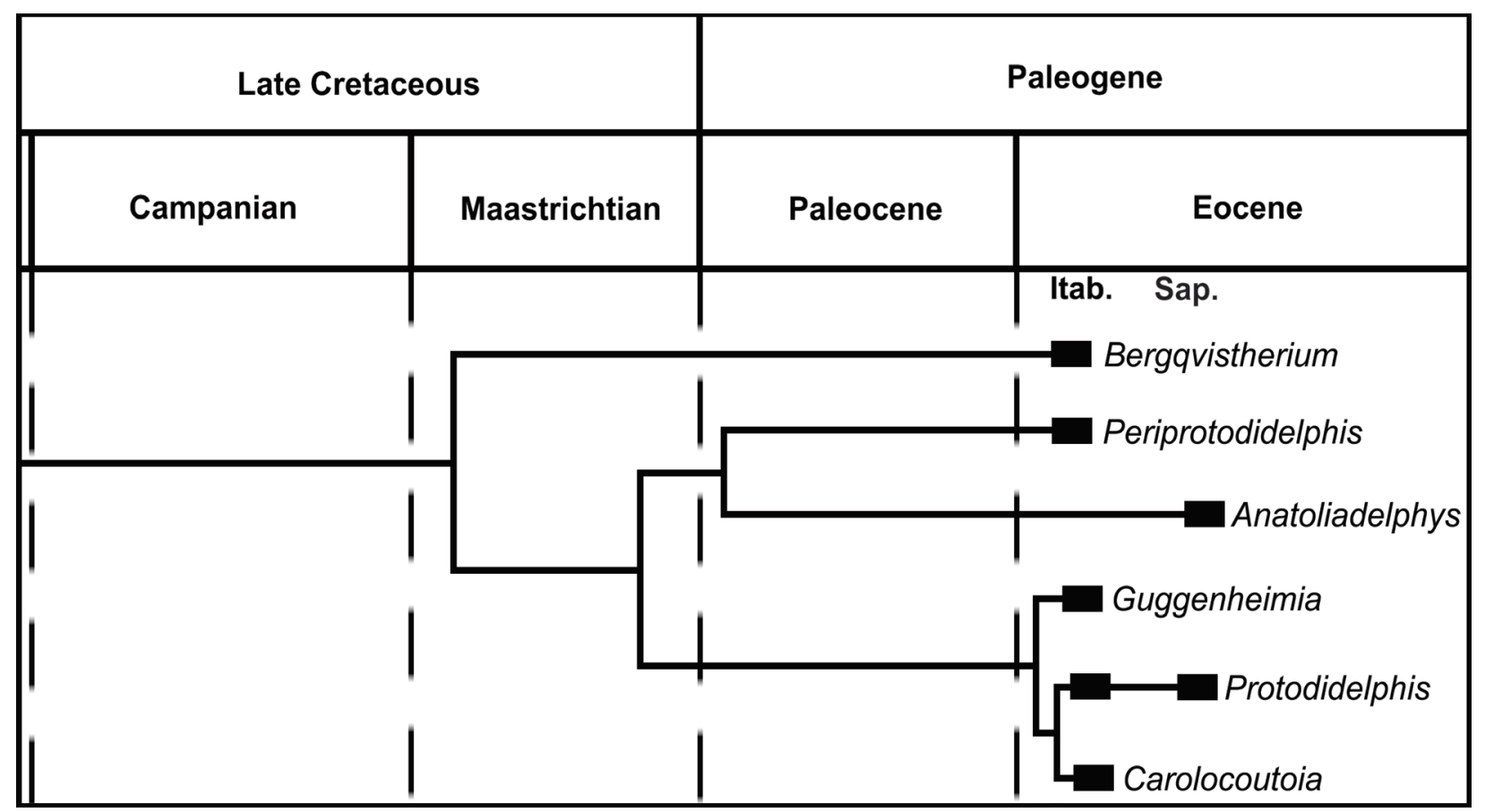

Figure 5 - Temporal cladogram of the Protodidelphidae. Phylogeny of the Protodidelphidae calibrated in time, based on the phylogeny present in the figure 4. The wide bars indicate the recorded temporal range of the Protodidelphidae genera. The SALMAs that present protodidelphids are identified. SALMAs: Itaboraian; "Sapoan". 
2011). The protodidelphids recovered in most of the collections at this locality show a greater number of apomorphies than Bergqvistherium and Periprotodidelphis (e.g. more brachyo-bunoid molars, larger size, relatively smaller paraconids and more inflated entoconids), which supports a more specialized frugivorous diet for them (Goin et al. 1998, Oliveira and Goin 2011, 2012, Zimicz A.N., unpublished data).

Woodburne et al. (2014a) placed the Itaboraí Basin during the lower Eocene (Itaboraian SALMA), being correlated with the Early Eocene Thermal Optimum (EETO); and Woodburne et al. (2014b) discussed the increase in extension of the tropical forests in South America after the PETM, which can be associated to the increase in the abundance and diversity of more bunoid mammals, like the protodidelphids Guggenheimia, Protodidelphis, and Carolocoutoia.

The phylogenetic analysis recovered Bergqvistherium and Periprotodidelphis as earlier divergent lineages of the Protodidelphidae, which supports an older origin for these two taxa than Guggenheimia, Protodidelphis, and Carolocoutoia. The existence of "basal" and apical faunal components in the Itaboraí Basin indicates that the diversification and increase in abundance of more apical and specialized frugivorous protodidelphids probably took place during the Itaboraian SALMA. The lower Eocene age dated for the Itaboraí Basin indicates that the diversification of Guggenheimia, Protodidelphis, and Carolocoutoia occurred in a relatively short time span, with the increase in the temperatures as the main environmental event correlated to the increase in size, brachyobunodonty and other frugivorous adaptations for these three genera.

The dental adaptations of Guggenheimia indicate the ingestion of hard food items, judging by the robust dentary and greater mesiodistal compression of the upper molars; Protodidelphis was more likely to be a frugivorous-generalist, and
Carolocoutoia a strict frugivorous (Zimicz A.N., unpublished data). This indicates an apparently lower niche overlapping between these three genera and a wide range of occupied trophic levels for this group, as Bergqvistherium is more likely to be a small frugivorous-generalist taxon.

The great taxonomical and ecological diversity of the Protodidelphidae from the Itaboraí Basin support the PETM as the main environmental event responsible for the evolution of the group. Some previous studies have proposed the hypothesis that the fossil bearing deposits of the Itaboraí Basin span a considerable age range (i.e. from the late Paleocene to early Eocene) (Gayet et al. 1991, Marshall et al. 1997, Rage 1998, Bergqvist et al. 2009, Pinheiro et al. 2012). This could be tentatively followed, as the protodidelphids of the Itaboraí Basin show a relative degree of morphological and ecological specialization, with "basal" and apical taxa in the same locality; however, the lower Eocene time span of the Itaboraí Basin, as proposed by Woodburne et al. (2014a, b), is here followed based on the bunoid adaptations present in the apical protodidelphids of this fauna, which are compatible with the increase of the extension of the tropical forests, as proposed by Woodburne et al. (2014b).

These evidences follow the results of Goin et al. (2012, 2016) and Woodburne et al. (2014a, b), who considered the Itaboraí Basin as lower Eocene in age, and attested the importance of the PETM as one of the most important environmental events during the Paleogene for the evolution of the South American metatherians.

The extinction of the Protodidelphidae could be related to the global cooling that happened during the Eocene, as no member of this lineage is known to have lived after the middle Eocene of South America and Antarctic (i.e. "Sapoan" SALMA - Woodburne et al. 2014a) (Fig. 5). 


\section{CONCLUSIONS}

The description of Bergqvistherium primigenia from the Itaboraí Basin increases the diversity of the Protodidelphidae in this locality. The presence of several plesiomorphic traits in this taxon supported its recovering in the phylogenetic analysis as an early-divergent protodidelphid.

The phylogenetic analysis supported a Late Cretaceous origin for the Protodidelphidae. Following the results, the increase in the abundance, trophic diversity and diversification of apical taxa of this group can be directly correlated to the environmental changes that occurred after the PETM.

The presence of "basal" and apical genera of the Protodidelphidae in the Itaborai Basin indicates that the diversification of more apical taxa was probably a result of a relatively shorttime evolutionary event during the time span of the Itaboraiense (early Eocene), as a response to the increase in temperatures and extension of the tropical forests in South America.

\section{ACKNOWLEDGMENTS}

I would like to thank Rodrigo da R. Machado (DNPM/RJ) and Luciana Carvalho (MN/RJ) for allowing access to the studied specimens, and Camila S. M. A. Messias for taking the SEM pictures of the studied specimen. I also would like to express my gratitude to Édison V. Oliveira and Francisco J. Goin for helping in the identification of this specimen and for their contributions to the knowledge of Itaboraís metatherians; Lílian P. Bergqvist for her support with the literature and discussion about the Itaboraí Basin; Leonardo dos S. Avilla, my doctorate advisor, who proposed the idea for the name of this new taxon as a tribute to Lílian Paglarelli Bergqvist, his doctorate advisor; and the Willi Henning Society for sponsoring the construction and allowing the free use of TNT. This work was supported by the Postgraduate
Program in Biodiversity and Evolutionary Biology of Universidade Federal do Rio de Janeiro (UFRJ) and Coordenação de Aperfeiçoamento de Pessoal de Nível Superior (CAPES).

\section{REFERENCES}

ABELLO MA. 2013. Analysis of dental homologies and phylogeny of Paucituberculata (Mammalia: Marsupialia). Biol J Linn Soc 109: 441-465.

BECK RMD. 2017. The skull of Epidolops ameghinoi from the Early Eocene Itaboraí Fauna, southeastern Brazil, and the affinities of the extinct Marsupialiform order Polydolopimorphia. J Mamm Evo: 1-42.

BERGQVIST LP, MANSUR K, RODRIGUES MA, RODRIGUES-FRANCISCO BH, PEREZ R AND BELTRÃO MC. 2009. Bacia São José de Itaboraí, RJ. Berço dos mamíferos no Brasil. In: Winge M, Schobbenhaus C, Souza CRG, Fernandes ACS, Berbert-Born M and Queiroz ET (Eds), Sítios Geológicos e Paleontológicos do Brasil. Brasilia: CPRM, Brazil, p. 1-15.

BININDA-EMONDS ORP ET AL. 2007. The delayed rise of present-day mammals. Nature 446: 507-512.

BOWEN GJ, MAIBAUER BJ, KRAUS MJ, RÖHL U, WESTERHOLD T, STEIMKE A, GINGERICH PD, WING SL AND CLYDE WC. 2015. Two massive, rapid releases of carbon during the onset of the PalaeoceneEocene thermal maximum. Nat Geosci 8: 44-47.

BOYD CA, PERSON JJ AND BARNES B. 2017. Additions to the Lancian mammalian fauna from southwest North Dakota. J Vert Paleontol: e1325368.

CARNEIRO LM. 2018. A new species of Varalphadon (Mammalia, Metatheria, Sparassodonta) from the upper Cenomanian of southern Utah, North America: phylogenetic and biogeographic insights. Cretac Res 84: 88-96.

CARNEIRO LM AND OLIVEIRA ÉV. 2017a. Systematic affinities of the extinct metatherian Eobrasilia coutoi Simpson, 1947, a South American early Eocene Stagodontidae: Implications for "Eobrasiliinae". Rev Bras Paleontolog 20: 355-372.

CARNEIRO LM AND OLIVEIRA ÉV. 2017b. The Eocene South American metatherian Zeusdelphys complicatus is not a protodidelphid but a hatcheriform: Paleobiogeographic implications. Acta Palaeontol Pol 62: 497-507.

CASE JA, GOIN FJ, AND WOODBURNE MO. 2005. "South American" Marsupials from the Late Cretaceous of North America and the Origin of Marsupial Cohorts. J Mamm Evol 12: 461-494. 
CLEMENS WA. 1966. Fossil mammals of the type Lance Formation, Wyoming. Part II. Marsupialia. Geology 62: $1-122$.

DAVIS BM. 2007. A revision of "pediomyid" marsupials from the Late Cretaceous of North America. Acta Palaeontol Pol 52: 217-256.

EZCURRA MD AND AGNOLÍN FL. 2012. A new global palaeobiogeographical model for the Mesozoic and early Tertiary. Syst Biol 61: 553-566.

FORASIEPI AM, GOIN FJ AND MARTINELLI AG. 2009. Contribution to the knowledge of the Sparassocynidae (Mammalia, Metatheria, Didelphoidea), with comments on the age of the Aisol Formation (Neogene), Mensonza Province, Argentina. J Vert Paleontol 29: 1252-1263.

FORASIEPI AM, BABOT MJ AND ZIMICZ N. 2015. Australohyaena antiqua (Mammalia, Metatheria, Sparassodonta), a large predator from the Late Oligocene of Patagonia. J Syst Palaeontol 13: 503-525.

GAYET M, MARSHALL LG AND SEMPERE T. 1991. The Mesozoic and Paleocene vertebrates of Bolivia and their stratigraphic context: a review. In: Suarez-Soruco R (Ed), Fosiles y facies de Bolivia - Vol. I Vertebratos, vol 12. Santa Cruz: Revista Technica de Yacimientos Petroliferos Fiscales Bolivianos, Bolivia, p. 393-433.

GELFO JN AND SIGÉ B. 2011. A new didolodontid mammal from the late Paleocene-earliest Eocene of Laguna Umayo, Peru. Acta Palaeontol Pol 56: 665-678.

GOIN FJ, OLIVEIRA ÉV AND CANDELA AM. 1998. Carolocoutoia ferigoloi nov. gen. And sp. (Protodidelphidae), a new Paleocene "opossum-like" marsupial from Brazil. Palaeovertebrata 27: 145-154.

GOIN, FJ, CASE JA, WOODBURNE MO, VIZCAÍNO SF AND REGUERO MA. 1999. New discoveries of "opossum-like" marsupials from Antarctica (Seymour Island, Medial Eocene). J Mamm Evol 6: 335-365.

GOIN FJ ET AL. 2006. The earliest Tertiary therian mammal from South America. J Vert Paleontol 26: 505-510.

GOIN FJ, GELFO JN, CHORNOGUBSKY L, WOODBURNE MO AND MARTIN T. 2012. Origins, radiations, and distribution of South American mammals: from greenhouse to icehouse worlds. In: Patterson BD and Costa LP (Eds), Bones, clones, and biomes: an 80-million year history of recent Neotropical mammals. Chicago: The University of Chicago Press., USA, p. 20-50.

GOIN FJ, WOODBURNE MO, ZIMICZ AN, MARTIN GM AND CHORNOGUBSKY L. 2016. Dispersal of vertebrates from between the Americas, Antarctica, and Australia in the Late Cretaceous and Early Cenozoic. In: Blondel P, Guilyardi E, Rabassa J and Horwood C (Eds), A brief history of South American Metatherians. New York: Springer, USA, p. 77-124.
GOLOBOFF PA AND CATALANO SA. 2016. TNT version 1.5 , including a full implementation of phylogenetic morphometrics. Cladistics 32: 221-238.

KIRSCH JWA, LAPOINTE F AND SPRINGER MS 1997. DNA-hybridization studies of marsupials and their implication for metatherian classification. Aust J Zool 45: 211-280.

LADEVÈZE S AND MUIZON C. 2010. Evidence of early evolution of Australidelphia (Metatheria, Mammalia) in South America: phylogenetic relationships of the metatherians from the Late Palaeocene of Itaboraí (Brazil) based on teeth and petrosal bones. Zool J Linn Soc 159: 746-784.

LUO Z, YUAN C, MENG Q AND JI Q. 2011. A Jurassic eutherian mammal and divergence of marsupials and placentals. Nature 476: 442-445.

MAGA AM AND BECK RMD. 2017. Skeleton of an unusual, cat-sized marsupial relative (Metatheria: Marsupialiformes) from the middle Eocene (Lutetian: 4443 million years ago) of Turkey. PLoS One 12: e0181712.

MARSHALL LG. 1987. Systematics of Itaboraian Age “opossum-like" Marsupials. In: Archer M (Ed), Possums and Opossums: studies in evolution. Sydney: Surrey Beatty and Sons Pty Limited, Chipping Norton, and the Royal Zoological Society of New South Wales, Australia, p. 91-160.

MARSHALL LG, SEMPERE T AND BUTLER RF. 1997. Chronostratigraphy of the mammal-bearing Paleocene of South America. J South Am Earth Sci 10: 49-70.

MCKENNA MC AND BELL SK. 1997. Classification of mammals above the species level. New York: Columbia University Press, USA, 613 p.

MUIZON C. 1992. La fauna de Mamiferos de Tiupampa (Paleoceno Inferior, Formacion Santa Lucia), Bolivia. In: Suarez-Soruco R (Ed), Fosiles y facies de Bolivia - I Vertebrados. Santa Cruz: Revista Técnica de YPFB 12, Bolivia, p. 575-624.

MUIZON C, BILLET G, ARGOT C, LADEVÈZE S AND GOUSSARD F. 2015. Alcidedorbignya inopinata, a basal pantodont (Placentalia, Mammalia) from the early Palaeocene of Bolivia: anatomy, phylogeny and palaeobiology. Geodiversitas 37: 397-634.

OLIVEIRA ÉV AND GOIN FJ. 2011. A reassessment of bunodont Metatherians from the Paleogene of Itaborai (Brazil): systematics and age of the Itaboraian SALMA. Rev Bras Paleontol 14: 105-136.

OLIVEIRA ÉV AND GOIN FJ. 2012. Metatérios do início do Paleógeno no Brasil: diversidade e afinidades. In: Cáceres NC (Ed), Os marsupiais do Brasil. Campo Grande: Editora UFMS, Brazil, p. 275-310.

PAULA COUTO C. 1952. Fossil Mammals from the beginning of the Cenozoic in Brazil Marsupialia: Didelphidae. Am Mus Novit 1567: 1-26. 
PAULA COUTO C. 1962. Didelfideos fosiles del Paleoceno de Brasil. Rev Mus Argent Cienc Nat Cienc Zool 12: 135 166.

PAULA COUTO C. 1970. News on the fossil marsupials from the Riochican of Brazil. An Acad Bras Cienc 42: 19-34.

PINHEIRO AEP, FORTIER DC, POL D, CAMPOS DA AND BERGQVIST LP. 2012. A new Eocaiman (Alligatoridae, Crocodylia) from the Itaboraí Basin, Paleogene of Rio de Janeiro, Brazil. Hist Biol 25: 327-337.

RAGE JC. 1998. Fossil snakes from the Palaeocene of Sao Jose de Itaborai, Brazil. Part I. Madtsoiidae, Aniliidae. Palaeovertebrata 27: 109-144.

SIGÉ B, SEMPERE T, BUTLER RF, MARSHALL LG AND CROCHET J. 2004. Age and stratigraphic reassessment of the fossil-bearing Laguna Umayo red mudstone unit, SE Peru, from regional stratigraphy, fossil record, and paleomagnetism. Geobios 37: 771-794.

TEJEDOR MF ET AL. 2009. New early Eocene mammalian fauna from western Patagonia, Argentina. Am Mus Novit 3638: 1-43.

VULLO R, GHEERBRANT E, MUIZON C AND NÉRAUDEAU D. 2009. The oldest modern therian mammal from Europe and its bearing on stem marsupial paleobiogeography. Proc Nat Acad Sci U S A 106: 1991019915.

WILLIAMSON TE, BRUSATTE SL, CARR TD, WEIL A AND STANDHARDT BR. 2012. The phylogeny and evolution of Cretaceous-Palaeogene metatherians: cladistic analysis and description of new early Palaeocene specimens from the Nacimiento Formation, New Mexico. J Syst Palaeontol 10: 625-651.

WILLIAMSON TE, BRUSATTE SL AND WILSON GP. 2014. The origin and early evolution of metatherian mammals: the Cretaceous record. Zookeys 465: 1-76.

WILSON PG, EKDALE EG, HOGANSON JW, CALEDE JJ AND LINDEN AV. 2016. A large carnivorous mammal from the Late Cretaceous and the North American origin of marsupials. Nat Commun 7: 13734.

WOODBURNE MO, GOIN FJ, RAIGEMBORN MS, HEIZLER M, GELFO JN AND OLIVEIRA ÉV. 2014a. Revised timing of the South American early Paleogene land mammals ages. J South Am Earth Sci 54: 109-119.

WOODBURNE MO, GOIN FJ, BOND M, CARLINI AA, GELFO JN, LÓPEZ GM, IGLESIAS A AND ZIMICZ AN. 2014b. Paleogene Land Mammal Faunas of South America; a response to global climatic changes and indigenous floral diversity. J Mamm Evol 21: 1-73. 